\title{
The Ethnicity of Tenth-Grade Students of Natural Science in Samarinda, East Kalimantan Province, Indonesia
}

\author{
Didimus Tanah Boleng \\ Biology Education Program \\ Teacher Training and Education Faculty of \\ Mulawarman University \\ Samarinda, Indonesia \\ didimus.tanahboleng@yahoo.com
}

\author{
Elsje Theodora Maasawet \\ Biology Education Program \\ Teacher Training and Education Faculty of \\ Mulawarman University \\ Samarinda, Indonesia \\ emaasawet@gmail.com
}

\begin{abstract}
Students' ethnic forms the character of students. Students' characters influence the way they learn, and ultimately affect student learning outcomes. A survey study was conducted in senior high school, Samarinda city, Indonesia, in the academic year of 2018/2019. The aim of this study was to determine the distribution of tenth grade students of natural science based on their ethnicity. The subject of the research was 718 of tenth grade student of natural science from several senior high school in Samarinda that selected by purposive sampling. The research instrument was a questionnaire and the data was analyzed using descriptive (percentage) technique. The results study showed that 6 ethnic groups dominated other ethnicities, namely Javanese (27.98\%), Banjar (17.78\%), Buginese (10.84\%), Kutai (11.27\%), Dayak $(10.62 \%)$, and Toraja $(9.97 \%)$; other ethnic groups are $11.56 \%$. It can be concluded that the tenth grade of natural science students of the natural sciences have various ethnic backgrounds.
\end{abstract}

Keywords: ethnic, natural sciences, senior high school

\section{INTRODUCTION}

The factors that influence the learning process of biology in senior high school are from external student i.e. curriculum, learning models, teachers, learning resources, and external motivation, and internal of students such as internal motivation and student character (ethnicity of students).

Certain ethnic students tend to have the specific characteristics of the students concerned. Student characters tend to influence students in their activities, including in the learning process with biology material in the classroom. Therefore, it is expected that students' character influences students in a positive attitude, in interacting with other students and teacher in classroom. Thus, the conditions of learning with students of different ethnic backgrounds, and with biological material; are conducive and mutually reinforcing among students. The learning process refers to ethnic socialization. Ethnic socialization denotes the development process where children learn about behavior, perception, values, and manners in an ethnic group besides beginning to see themselves and others as members in a group [1]. In addition, the expected learning outcomes were achieved to the maximum.
According to students' ethnic of eleventh grade students of natural science, senior high schools in Samarinda City, in the academic year of 2018/2019, Boleng reported the results of their study of 869 students, there were four major ethnic groups that dominated the other ethnicities. The four ethnics are Javanese $(36.13 \%)$, Buginese $(10.12 \%)$, Kutai $(10.12 \%)$, and Banjar (14.84\%). Other ethnicities are 27.68; consists of other ethnic groups, both local and migrant ethnic groups [2].

The ethnic condition of eleventh grade students of natural science students in senior high school in the academic year of 2018/2019 in Samarinda city is unknown. In addition, the ethnicity of the student parents of eleventh grade of natural sciences students in senior high school is not known yet. Therefore, effective learning strategies, which need to be designed by teachers based on the student ethnic background in classroom has not been determined. Survey is an effective technique to obtain the ethnic information of students. In addition, information about the ethnicity of students can be obtained directly from students. Singarimbun explained the objectives of research survey were (1) exploratory (explorative), (2) descriptive, (3) explanatory (explanatory or confirmatory), (4) evaluation, (5) prediction or predicting and testing hypotheses, (6) operational research, (7) development of social indicators [3]. Thus, the survey conducted was able to reveal the ethnic condition of tenth grade students of natural science. The aim of the study was to distribute the tenth grade student of natural science of senior high school based on their ethnicity, in the academic year of 2018/2019.

\section{METHOD}

This type of research was a survey. The study was directed at collecting data in the form of ethnic of students, without the research team's treatment. Population in this study was all tenth grade students of natural sciences from both of public and private senior high schools in Samarinda city, East Kalimantan, Indonsia, in the academic year of 2018/2019. The sample of this research was a group of tenth grade students of natural science, senior high school in Samarinda city. The survey was conducted from May to July, 2019 in several senior high schools in Samarinda city including SMA N 1 Samarinda, SMA N 3 Samarinda, SMA N 6 Samarinda, SMA N 8 Samarinda, SMA N 12 Samarinda, SMA N 13 Samarinda, SMA N 14 Samarinda, and SMA N 17 Samarinda. The total number of students using as sample 
transmigration program to East Kalimantan Province that was held by government. Koentjaraningrat explained that there were obstacles in village development in Java, one of which was high population growth caused rural communities in Java to become poor [7].

The arrival of Bugis people to Samarinda was influenced by the close distance between the islands of Kalimantan and Sulawesi, and looking for work. Ismail stated that Buginese beliefs are similar to Southeast Asian people in strength or vitality, being distributed throughout the cosmos. In fact, they assume that every object has a passion (sumange), to fulfill their welfare. [8].

Sonhadji explained that language and dialect generally reflect different ethnic groups. In other words, the Indonesian nation is pluralistic and multicultural [9].

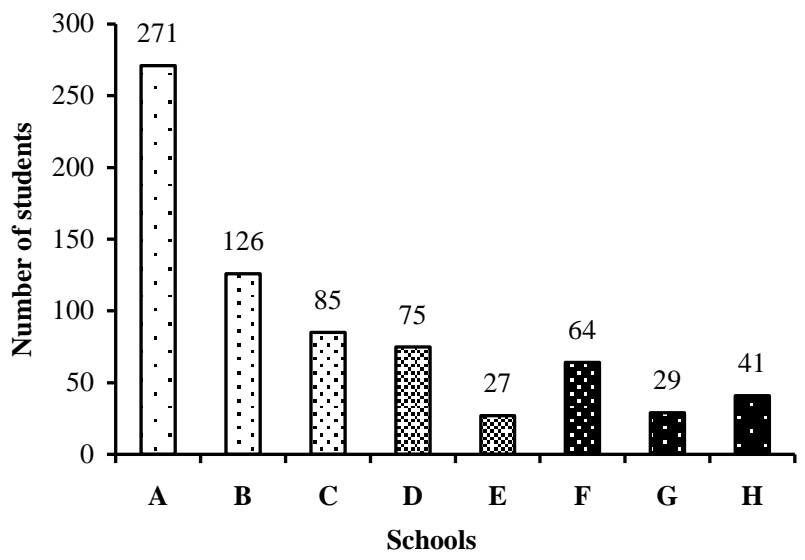

Fig. 1. Number of tenth-grade students of natural sciences of each schools, Notes: A is SMA N 1 Samarinda, B is SMA N 3 Samarinda, C SMA N 6 Samarinda, D is SMA N 8 Samarinda, E is SMA N 12 Samarinda, F is SMA N 13 Samarinda, G is SMA N 14 Samarinda, and H is SMA N 17 Samarinda achievement [5].

\section{B. Distribution of students based on ethnicity}

Distribution of tenth grade students of natural science from several schools in Samarinda city in the academic year of 2018/2019 is shown in Table 1, 23 ethnics were identified. According to table 1, there are 6 ethnics i.e. Javanese $(27.98 \%)$, Banjar (17.78\%), Buginese $(10.84 \%)$, Kutai (11.27\%), Dayak (10.62\%), and Toraja (9.97\%). Kutai, Dayak and Banjar are native ethnics in Kalimantan, and Javanese, Buginese and Toraja are migrant ethnics. The migrant ethnic groups came to Samarinda, East Kalimantan Province, caused by high population pressure in their home areas. They migrated independently or joined the transmigration program.

Java is one of the migrant ethnics in East Kalimantan Province, including Samarinda city. Javanese have inherited positive character from their ancestors. Idrus explained that Javanese always bequeath good attitude i.e. fear (wedi), shame (isin), and respect (sungkan) [6]. Those positive characters allow Javanese to interact with other ethnic groups. They can survive with other ethnic groups in Samarinda city. The high number of Javanese in Samarinda city is also caused by the high migration enthusiasm of them to East Kalimantan Province, especially Samarinda city. Some community groups of Javanese participated in
TABLE I. THE Number OF TENTH GRADE STUDENTS OF NATURAL SCIENCE ACCORDING TO THEIR ETHNIC IN SAMARINDA CITY IN THE ACADEMIC YEAR OF 2018/2019

\begin{tabular}{|c|l|c|c|}
\hline No. & \multicolumn{1}{|c|}{ Ethnics } & N & $\%$ \\
\hline 1 & Javanese & 201 & 27.98 \\
2 & Banjar & 128 & 17.78 \\
3 & Buginese & 78 & 10.84 \\
4 & Kutai & 81 & 11.27 \\
5 & Dayak & 76 & 10.62 \\
6 & Toraja & 71 & 9.97 \\
7 & Sunda & 6 & 0.84 \\
8 & Batak & 3 & 0.42 \\
9 & Mandar & 1 & 0.14 \\
10 & Minang & 4 & 0.56 \\
11 & Buton & 6 & 0.84 \\
12 & Manado & 7 & 1.25 \\
13 & Flores & 2 & 0.10 \\
14 & Aceh & 3 & 0.28 \\
15 & Minahasa & 2 & 0.42 \\
16 & Melayu & 5 & 0.28 \\
17 & Lombok & 6 & 0.70 \\
18 & Balinese & 8 & 0.84 \\
19 & Madura & 4 & 1.11 \\
20 & Bulungan & 6 & 0.56 \\
21 & Bakumpai & 6 & 0.84 \\
22 & Betawi & 5 & 0.84 \\
23 & Sangir & 718 & 0.70 \\
\hline & & & 100 \\
\hline
\end{tabular}




\section{Classroom learning with multiethnic student conditions}

Student ethnics influence learning process in classroom. Teacher needs to pay attention on the student ethnics during designing lesson plan. Model in learning process has to allow students in multiethnic interact each other. The student interactions in learning process enable to develop positive student attitudes, and help and reinforces each another. Sonhadji explained that each individual or group in the community must continue to respect cultural varieties (cultural diversity) which originate from ethnic, religious or cultural differences in which individuals or groups show [9]. Positive attitude of students can also be built by the guidance of parents in the family. Davies suggest that additional studies that also explore multiple constructs will enable researchers to begin to form understandings about the interrelationships of psycho-social variables and relations with achievement [10].

Student parents with certain ethnic backgrounds are expected to provide guidance according to their ethnic character in learning at home and school. Parental guidance patterns determine the direction of student learning. Slameto stated that habits in family affect student learning [3]. Kuswarno added that it is important to pay attention to cultural aspects in the process of ethnographic communication [11]. Aunillah also added that teachers and parents of students also have to care about other people, even unknown people [12].

Good awareness from students and teachers is needed in multi-ethnic learning. Students have to feel equal each other, although they are minority ethnics. Tolerance is also needed in the learning process. In addition, with different characters, they are expected to be able to help and strengthen each other in the learning process. Thus, learning objectives can be achieved. Batarchuk stated that a positive attitude, neutral towards foreigners, is caused by inappropriate abilities towards emotional conditions, influencing the appearance of stereotypes, and perceptions of emotional [13]. Ananina also added that, lately there were serious challenges in preserving ethnic identity, and at the same time being integrated into a different ethnic group [14].

\section{CONCLUSION}

Student ethnic of tenth grade students of natural science from several public high schools in Samarinda in the academic year of 2018/2019 was 23 ethnics. Six dominant ethnics were Javanese (27.98\%), Banjar (17.78\%), Buginese (10.84\%), Kutai (11.27\%), Dayak (10.60\%), and Toraja
(9.97\%). Other ethnics were $11.56 \%$. It is expected that teacher plans biology learning with a learning model that allows all students from all ethnic groups to interact each other.

\section{ACKNOWLEDGMENT}

The research team would like to thank the Dean of Faculty of Teacher Training and Education, Mulawarman University, Indonesia, for granting funding in the 2019 Research Grant, for supporting the research.

\section{REFERENCES}

[1] Y. Ahmad, and N.M. Yusof, "Ethnic boundary among students in Malaysian primary schools and social interaction: A conceptual framework," Procedia-Social and Behavioral Sciences, vol. 7, 2010, pp. 82-91.

[2] D.T. Boleng, The influence of implementation of combination problem-based and think-pair-share learning models critical thinking skills and biological concept understanding of multi-ethnic students at senior high school in Samarinda, Pengaruh penerapan model pembelajaran problem-based learning dipadu dengan think-pair-share terhadap keterampilan berpikir kritis dan pemahaman konsep biologi siswa multietnis Sekolah Menengah Atas di Kota Samarinda, Samarinda: Fakultas Keguruan dan Ilmu Pendidikan, Universitas Mulawarman, 2018.

[3] M. Singarimbun, and S. Effendi, Survey research methodology, Metodologi Penelitian Survei, Jakarta: LP3ES, 1989.

[4] Slameto, Learning and influencing factors, Belajar dan faktor-faktor yang mempengaruhi, Jakarta: Rineka Cipta, 2010.

[5] R. Bakar, "The Influence of professional teachers on Padang Vocational School Students' achievement." Kasetsart Journal of Social Sciences, vol. 39.1, 2018, pp. 67-72.

[6] M. Idrus, "Character education in Javanese families," "Pendidikan karakter pada keluarga jawa," Jurnal Pendidikan Karakter, vol. 2, 2012, pp. 118-130.

[7] Koentjaraningrat, Humans and culture in Indonesia, Manusiadan kebudayaan di Indonesia, Jakarta: Djambatan, 2008.

[8] W.H.W. Ismail, "Cultural determinants in the design of bugis houses," Procedia Soc Behav Sci, vol. 50, 2012, pp. 771-780.

[9] A.S. Sonhadji, Human, technology and education, Manusia, teknologi, dan pendidikan, Malang: UM Press, 2012.

[10] Davies, E. Peterson, L. Garrett, and P. Watson, "Ethnicity as a factor in student beliefs", Procedia Soc Behav Sci, vol. 69, 2012, pp. 262 270.

[11] E. Kuswarno, Ethnography of communication, Etnografi komunikasi, Bandung: Widya Padjajaran, 2008.

[12] Aunillah, Character education in school, Pendidikan karakter di sekolah, Jogjakarta: Laksana, 2011.

[13] D.S. Batarchuk, "The Problem of interethnic youth relations in multiethnic educational environment," Procedia Soc Behav Sci, vol. 237, 2017, pp. 1589-1592.

[14] V. Ananina, and D. Danilov,"Ethnic tolerance formation among students of Russian Universities: Current state, problems, and perspectives," Procedia Soc Behav Sci, vol. 214, 2015, pp. 487-496. 